\title{
DAMPAK MODAL SOSIAL TERHADAP KEPUTUSAN PENDANAAN \\ DALAM MENGELOLA TEKANAN KEUANGAN \\ (Studi Pada UMK Batik di Kota Semarang)
}

\author{
Suryakusuma K.H, Siti Puryandani \\ suryakusumakh7@gmail.com \\ Program Studi Manajemen, STIE Bank BPD Jateng.
}

\begin{abstract}
The purpose aim how financial performance in a business situation have financial distress and how entrepreneurs react to environmental changes and take advantage of the social capital for sustainability.This study will investigate the social capital, the financial decision and financial distress. The research objects are SME Batik Semarang thats tenant by goverment bank in Semarang. The SME Batik have operational during 2017 and total questionare are collecting 36 SME Batik.The result argue that social capital have impact to the financing decision and financing decision eventually influences financial distress.
\end{abstract}

Keyword : social capital, financing decision, and financial distress.

\begin{abstract}
ABSTRAK
Tujuan dari penelitian ini menganalisis bagaimana kinerja keuangan dalam kondisi bisnis yang mengalami tekanan keuangan dan bagaimana pelaku usaha bereaksi terhadap perubahan lingkungan dan memanfaatkan keberadaan modal sosial agar keberlanjutan perusahaan dapat dipertahankan. Penelitian ini akan mengkaji variabel modal sosial, keputusan pendanaan dan tekanan keuangan. Obyek penelitian adalah pelaku UKM Batik di Kota Semarang yang sudah menjadi binaan dan masih melakukan operasional sampai tahun 2017 sebanyak 36 pelaku UKM Batik. Hasil penelitian menunjukkan bahwa modal sosial berdampak terhadap keputusan pendanaan dan keputusan pendanaan pada akhirnya berpengaruh terhadap tekanan keuangan yang dihadapi oleh UKM Batik.
\end{abstract}

Kata kunci: modal sosial, keputusan pendanaan dan tekanan keuangan

\section{Pendahuluan}

Salah satu ujung tombak industri nasional adalah usaha mikro dan kecil (UMK), yang memegang peranan penting dalam perekonomian karena dapat menyerap tenaga kerja, menyumbang devisa dan ikut membayar pajak. UMK juga memiliki daya tahan terhadap krisis ekonomi karena lebih fleksibel dalam 
menghadapi dan beradaptasi dengan perubahan pasar. Peran UMK tidak diragukan lagi dalam menyokong ekonomi nasional. Namun demikian UMK bukannya tanpa kendala, UMK juga memiliki berbagai kendala umum sebagaimana yang di identifikasikan oleh Badan Pusat Statistik (2007) antara lain: kurang permodalan, kesulitan pemasaran, persaingan usaha ketat, kesulitan bahan baku, kurang teknis produksi dan keahlian, keterampilan manajerial kurang, kurang pengetahuan manajemen keuangan dan iklim usaha yang kurang kondusif seperti perijinan, aturan atau perundangan. Kendala tersebut menjadikan para UMK memiliki kelemahan yaitu kemampuan yang terbatas dalam mengakses informasi dan sangat tergantung dari pengusaha besar. Kelemahan tersebut menyebabkan kekurangmampuan para pengusaha dalam memanfaatkan peluangpeluang yang ada.

Kota Semarang merupakan salah satu penggiat industri batik. Ini merupakan potensi yang sangat besar untuk terus dikembangkan, sehingga kontribusinya terhadap perekonomian daerah juga makin signifikan. Total nilai bisnis industri batik di kota Semarang tahun 2015 tercatat Rp 2,3 milyar. Jumlah UMK yang terlibat di industri ini mencapai 48 UMK, sementara jumlah tenaga kerjanya 271 orang. Sekitar $84 \%$ produk batik dijual ke pasar ke pasar dalam negeri. Upaya yang telah dilakukan oleh pemerintah kota Semarang adalah memperbaiki sejumlah fasilitas yang ada untuk mendorong perkembangan sentra industri batik di kota ini. Misalnya memperkuat fasilitas umum, seperti pusat batik Sobokarti. Pusat batik yang dibuka pada 2007 ini terdiri atas pusat promosi (yang juga berfungsi sebagai balai lelang), pusat informasi, pusat desain, serta advokasi atas hak dan kekayaan intelektual (Jawa Tengah dalam Angka, 2015). Namun permasalahan internal seperti : semakin kurangnya bahan baku, motif dan desain yang monoton, rendahnya kualitas produk dibandingkan produksi batik Lasem, Pekalongan dan Solo membuat industri batik di kota Semarang mengalami penurunan kinerja.

Kompleksitas permasalahan yang dihadapi, tekanan faktor eksternal dan kelemahan secara internal jika tidak dikelola secara baik akan membuat UMK dalam jangka pendek terganggu dalam mempertahankan likuiditasnya. Dengan 
kata lain, kemampuan UMK untuk memenuhi kewajiban jangka pendek yang jatuh tempo akan makin rendah (low liquidity). Pada tahapan berikutnya likuiditas yang rendah akan membuat perusahaan berada dalam tekanan keuangan (financial distress). Jika UMK tidak berhasil melakukan upaya pemulihan, hal tersebut akan berdampak pada kekurangmampuan UMK dalam meningkatkan kinerja perusahaan. Dalam hal ini, tekanan keuangan berpengaruh positif dengan potensi kebangkrutan dimana jika terdapat kemungkinan bangkrut maka biaya administrasi dan biaya lainnya yang berhubungan dengan kebangkrutan akan signifikan. Pada ambang batas tertentu mungkin UMK dapat bertahan, namun secara teori kondisi ini akan berhubungan negatif dengan kinerja perusahaan.

Penurunan kinerja keuangan yang sering disebut sebagai financial distress dapat dialami oleh berbagai perusahaan besar ataupun kecil dari berbagai sektor industri. Dalam siklus hidup perusahaan, penurunan kinerja keuangan dapat terjadi karena faktor internal maupun eksternal (Roudledge \& Gadenne, 2008). Menurut Platt dan Platt (2002), financial distress didefinisikan sebagai tahap penurunan kondisi keuangan sebelum terjadinya kebangkrutan atau likuidasi. Kebangkrutan adalah kesulitan likuiditas yang sangat parah sehingga perusahaan tidak mampu menjalankan operasi dengan baik. Sistem peringatan untuk mengantisipasi adanya financial distress perlu dikembangkan karena dapat digunakan sebagai sarana untuk mengidentifikasikan bahkan untuk memperbaiki kondisi sebelum sampai pada kebangkrutan. Sehingga dapat disimpulkan financial distress adalah situasi di mana arus kas hasil operasi perusahaan tidak cukup untuk memenuhi kewajiban perusahaan.

Lang et al (1992) memperlihatkan bahwa perusahaan dengan rasio likuiditas yang rendah memiliki peluang gagal (default) lebih besar dibandingkan perusahaan dengan rasio likuiditas yang tinggi. Rasio likuiditas yang ditunjukkan melalui besarnya kemampuan membayar hutang atau debt service coverage menjadi indikator untuk tekanan keuangan. Tekanan keuangan yang dihadapi oleh perusahaan akan berdampak pada semakin memburuknya kinerja keuangan jika tidak diimbangi dengan strategi pemulihan yang tepat, Roufledge \& Gadenne (2008) dan Avranov et al (2013). Kegagalan manajemen didefinisikan sebagai 
dampak keputusan-keputusan manajemen yang kurang optimal dalam mengatasi financial distress atau ketidakmampuan pihak manajemen menerapkan kebijakan yang diperlukan. Ketidakmampuan ini mengakibatkan internal kontrol yang tidak memadai karena kegagalan mengolah informasi, kelemahan struktur organisasi, atau pembuatan keputusan dan manajemen yang salah (Laitinen, 2011).

Dari sudut pandang perspektif psikologi keuangan (psychological finance) menyatakan manajer cenderung bertindak dengan tingkat kepercayaan yang berlebihan (overconfidence) dalam mengelola tekanan keuangan agar nilai perusahaan dapat ditingkatkan. Laster et al (1996) dalam penelitiannya memperlihatkan manajer dengan tingkat penyesuaian yang tinggi (high adaptability) akan lebih dapat mengendalikan situasi pada saat perusahaan mengalami tekanan keuangan. Lebih luas lagi Mailath dan Postlewaite (2003) dalam penelitiannya mencoba melihat bagaimana perilaku usaha kecil menengah dalam mensikapi tekanan keuangan yang dialami dikaitkan dengan konsep modal sosial (social capital). Hasilnya bahwa setiap UMK di negara-negara yang berbeda memiliki keenekaragaman dalam pola hubungan, dilihat dari bagaimana pelaku UMK mengimplementasikan aset sosial yang dimiliki. Secara khusus modal sosial diartikan sebagai sumberdaya yang diperoleh para pelaku UMK atas interaksinya dalam jaringan hubungan, modal sosial diketahui berpengaruh secara langsung dengan memberikan akses atas informasi, dukungan keuangan, dukungan emosional, legimitasi serta kemampuan bersaing serta pengambilan keputusan pada saat terjadi krisis ekonomi (economic shock). Dengan kata lain dapat dikatakan bahwa UMK yang mampu mengelola modal sosial yang dimiliki relatif dapat bertahan dalam menghadapi tekanan keuangan, bahkan dengan dukungan penuh dari pemerintah selaku pembuat kebijakan terbukti mampu membuat UMK tetap berkembang setelah melewati tekanan keuangan.

Nguyen dan Ramachandran (2006) menemukan bahwa perusahaan yang mampu membangun hubungan sosial yang baik dengan instutusi keuangan akan memiliki kesempatan untuk memperoleh fasilitas pembiayaan bunga rendah. Du et al (2010), dalam penelitiannya juga memberikan gambaran bahwa modal sosial dapat menjelaskan bagaimana keputusan pendanaan yang diambil oleh 
perusahaan. Dengan modal sosial yang dimiliki, perusahaan akan memiliki relasi positif dengan pelaku ekonomi lainnya, dimana dengan adanya relasi ini akan memperkuat akses kepada sumber-sumber pendanaan dari luar. Semakin kuat relasi yang dibangun maka modal sosial akan makin kuat, dampak terhadap pendanaan adalah jumlah hutang yang dapat dihimpun akan lebih tinggi dan kemudahan akses, hal ini berbeda jika dibandingkan dengan relasi yang lemah atau formal karena penilaian yang berbasis kolateral nilai agunan.

\section{Kajian Teoritis}

\subsection{Teori Modal Sosial (Social Capital)}

Definisi modal sosial secara sederhana menurut Fukuyama (2001) adalah "an instantiated informal norm that promotes co-operation between two or more individuals. By this definition, trust, networks, civil society, and the like, which have been associated with social capital, are all epiphenominal, arising as a result of social capital but not constituting social capital it self'. Modal sosial memiliki peran yang sangat penting pada beberapa kelompok masyarakat dalam berbagai aktivitas. Namun Fukuyama juga mengatakan bahwa tidak semua norma, nilai dan budaya secara bersama-sama dapat saling melengkapi untuk mendukung pertumbuhan ekonomi. Sama seperti halnya modal fisik dan modal finansial, modal sosial juga bisa menimbulkan dampak negatif karena modal sosial dibangun oleh kepercayaan-kepercayaan antar individu. Rasa saling percaya dibentuk dalam waktu yang tidak sebentar serta memerlukan proses-proses sosial yang berliku.

Modal sosial mempunyai fungsi yang sangat penting dalam hubungan antar manusia. Ife dan Tesoriero (2008) mengatakan bahwa modal sosial dapat dilihat sebagai 'perekat' yang menyatukan masyarakat, hubungan-hubungan antar manusia, orang melakukan apa yang dilakukannya terhadap sesamanya karena ada kewajiban sosial, timbal balik, solidaritas sosial dan komunitas. Dalam pengertian yang dikemukakan Ife dan Tesoriero, modal sosial mengarahkan orang untuk berbagai kekuatan (power sharing) yang dilandasi oleh nilai-nilai dan normanorma kehidupan. 
Sedikit berbeda dengan definisi yang dikemukakan oleh beberapa ahli sebelumnya, Putnam (2001) mengatakan bahwa modal sosial adalah "similar to the notions of physical and human capital, the term social capital refers to featurs of social organization - such as network, norms and trust that increase a society's productive potenstial". Dengan definisi ini Putnam menyatakan bahwa kepercayaan (trust), jaringan (network) dan civil society adalah sesuatu yang lahir dari adanya modal sosial dan bukan merupakan modal sosial itu sendiri. Pernyataan Putnam hampir senada dengan yang dikemukakan oleh Coleman (2009) yang mengatakan bahwa modal sosial tercipta ketika relasi antara orangorang mengalami perubahan sesuai dengan cara-cara yang memudahkan tindakan.

\subsection{Dimensi Modal Sosial}

Modal sosial berbeda dari modal lainnya. Apabila modal manusia (human capital) dapat dilihat dan diukur dari pengetahuan dan keterampilan yang dikuasai oleh seseorang maka modal sosial hanya dapat dirasakan dari kapabilitas yang muncul dari kepercayaan umum dalam sebuah masyarakat atau bagian-bagian di dalamnya. Menurut Fukuyama (2001) modal sosial ditransmisi melalui mekanisme-mekanisme kultural, tradisi atau kebiasaan sejarah. Modal sosial dibutuhkan untuk menciptakan komunitas moral yang tidak bisa diperoleh atau dibentuk seperti dalam pembentukan modal manusia. Penanaman dan pengembangan modal sosial memerlukan pembiasaan terhadap norma-norma moral sebuah komunitas dan dalam konteksnya sekaligus mengadopsi kebajikankebajikan seperti kejujuran, kesetiaan dan kemandirian.

Menurut Woolcock dan Narayan dalam Agus Supriono dkk (2009), dimensi modal sosial tumbuh pada suatu masyarakat yang di dalamnya berisi nilai, norma dan pola-pola interaksi sosial yang mengatur kehidupan keseharian anggotanya. Adler dan Kwon (2003) mengatakan bahwa "dimensi modal sosial merupakan gambaran dari keterikatan internal yang mewarnai struktur kolektif dan memberikan kohesifitas dan keuntungan-keuntungan bersama dari proses dinamika yang terjadi dalam masyarakat”. Dasgupta dan Serageldin (1996) mengemukakan bahwa "dimensi modal sosial menggambarkan segala sesuatu 
yang membuat masyarakat bersekutu untuk mencapai tujuan bersama atas dasar kebersamaan dan di dalamnya diikat oleh nilai-nilai dan norma-norma yang tumbuh dan dipatuhi”. Coleman (2009) menggambarkan dimensi modal sosial secara rinci dengan mengemukakan bahwa dimensi modal sosial inhern dalam struktur relasi sosial dan jaringan sosial di dalam suatu masyarakat yang menciptakan berbagai ragam kewajiban sosial, menciptakan iklim saling percaya, membawa saluran informasi dan menetapkan norma-norma serta sanksi-sanksi sosial bagi para anggota masyarakat tersebut.

Dari pernyataan-pernyataan mengenai dimensi modal sosial tersebut, yang menjadi pertanyaan bagi peneliti adalah tidak adanya penjelasan mengenai agen atau tokoh yang menjadi poros atau panutan bagi anggota komunitas dalam mengembangkan relasi dan jaringan sosial yang terbentuk. Dalam banyak bentuk relasi sosial, dapat ditemui kesetaraan peran di antara pihak-pihak yang menjalin relasi, misalnya relasi pertemanan. Namun bagaimanapun juga, ada saat-saat tertentu di mana salah satu pihak lebih dominan terhadap pihak yang lain atau salah satu pihak memberikan pengaruh atau memberi arah yang kemudian diikuti oleh pihak lainnya. Demikian pula halnya dengan modal sosial. Penanaman nilainilai dan norma-norma, pembentukan jaringan sosial dan tumbuhnya gerakan untuk mencapai tujuan bersama mungkin saja terbentuk secara alamiah dari proses dan kehidupan sehari-hari dalam suatu komunitas tetapi pada waktu-waktu tertentu dan ketika menghadapi pihak dari luar komunitas, tentu harus ada orang yang mewakili untuk menyampaikan aspirasi atau menjawab pertanyaan (maupun tantangan) yang timbul. Dalam dimensi modal sosial, peran agen atau tokoh merupakan hal penting yang menjadi bagian tidak terpisahkan dari modal sosial itu sendiri. Sama halnya seperti dalam sebuah keluarga, di mana nilai-nilai kebajikan dan budi pekerti ditanamkan kepada anak (keturunan) oleh orang tuanya maka dalam membangun kepercayaan maupun relasi sosial serta menggunakan nilai-nilai dan norma-norma untuk menjadi pengikat dalam komunitas diperlukan adanya tokoh-tokoh yang dapat menjadi sentral dan dapat mempengaruhi seluruh anggota komunitas. 


\subsection{Keputusan Pendanaan}

Pada dasarnya tugas manajer keuangan perusahaan adalah berusaha mencari keseimbangan finansial neraca yang dibutuhkan, serta mencari susunan kualitatif neraca tersebut dengan sebaik-baiknya. Pemilihan susunan kualitatif pada sisi assets akan menentukan struktur kekayaan perusahaan, sedangkan pemilihan susunan kualitatif dari sisi liabilities dan equities akan menentukan struktur keuangan dan struktur modal perusahaan. Struktur modal harus dapat dibedakan dengan struktur keuangan. Struktur keuangan menyatakan dengan cara bagaimana harta perusahaan dibiayai. Oleh karena itu struktur keuangan adalah keseluruhan yang terdapat di dalam neraca sebelah kredit. Pada neraca sebelah kredit terdapat hutang jangka panjang maupun jangka pendek, dan modal sendiri baik jangka panjang maupun jangka pendek. Jadi struktur keuangan mencakup semua pembelanjaan baik jangka panjang maupun jangka pendek. Sebaliknya struktur modal hanya menyangkut pembelanjaan jangka panjang saja. Tidak termasuk pembelanjaan jangka pendek. Weston dan Copeland (1992) memberikan definisi struktur modal sebagai pembiayaan permanen yang terdiri dari hutang jangka panjang, saham preferen, dan modal pemegang saham. Nilai buku dari modal pemegang saham terdiri dari saham biasa, modal disetor atau surplus modal dan akumulasi laba ditahan. Bila perusahaan memiliki saham preferen, maka saham tersebut akan ditambahkan pada modal pemegang saham.

\subsubsection{Hutang Jangka Panjang}

Jumlah hutang di dalam neraca akan menunjukkan besarnya modal pinjaman yang digunakan dalam operasi perusahaan. Modal pinjaman ini dapat berupa hutang jangka pendek maupun hutang jangka panjang, tetapi pada umumnya pinjaman jangka panjang jauh lebih besar dibandingkan dengan hutang jangka pendek. Hutang jangka panjang merupakan salah satu dari bentuk pembiayaan jangka panjang yang memiliki jatuh tempo lebih dari satu tahun, biasanya $5-20$ tahun. Mengukur besarnya aktiva perusahaan yang dibiayai oleh kreditur (debt ratio) dilakukan dengan cara membagi total hutang jangka panjang dengan total asset. Semakin tinggi debt ratio, semakin besar jumlah modal pinjaman yang digunakan di dalam menghasilkan keuntungan bagi perusahaan. Beberapa hal 
yang menjadi pertimbangan manajemen sehingga memilih untuk menggunakan hutang adalah sebagai berikut:

1. Biaya hutang terbatas, walaupun perusahaan memperoleh laba besar, jumlah bunga yang dibayarkan besarnya tetap.

2. Hasil yang diharapkan lebih rendah daripada saham biasa

3. Tidak ada perubahan pengendalian atas perusahaan bila pembiayaan memakai hutang.

4. Pembayaran bunga merupakan beban biaya yang dapat mengurangi pajak

5. Fleksibilitas dalam struktur keuangan dapat dicapai dengan memasukkan peraturan penebusan dalam perjanjian obligasi.

Kreditur (investor) lebih memilih menanamkan investasi dalam bentuk hutang jangka panjang karena beberapa pertimbangan. Pemilihan investasi dalam bentuk hutang jangka panjang dari sisi investor didasarkan pada beberapa hal berikut:

1. Hutang dapat memberikan prioritas baik dalam hal pendapatan maupun likuidasi kepada pemegangnya.

2. Mempunyai saat jatuh tempo yang pasti.

3. Dilindungi oleh isi perjanjian hutang jangka panjang (dari segi resiko)

4. Pemegang memperoleh pengembalian yang tetap (kecuali pendapatan obligasi).

\subsubsection{Modal Sendiri}

Dalam struktur modal konservatif, susunan modal menitikberatkan pada modal sendiri karena pertimbangan bahwa penggunaan hutang dalam pembiayaan perusahaan mengandung resiko yang lebih besar dibandingkan dengan penggunaan modal sendiri. Modal sendiri/equity capital adalah dana jangka panjang perusahaan yang disediakan oleh pemilik perusahaan (pemegang saham), yang terdiri dari berbagai jenis saham (saham preferen dan saham biasa) serta laba ditahan. Pendanaan dengan modal sendiri akan menimbulkan opportunity cost. Keuntungan dari memiliki saham perusahaan bagi owner adalah control terhadap perusahaan. Namun, return yang dihasilkan dari saham tidak pasti dan pemegang 
saham adalah pihak pertama yang menanggung resiko perusahaan. Modal sendiri atau ekuitas merupakan modal jangka panjang yang diperoleh dari pemilik perusahaan atau pemegang saham. Modal sendiri diharapkan tetap berada dalam perusahaan untuk jangka waktu yang tidak terbatas sedangkan modal pinjaman memiliki jatuh tempo.

\subsubsection{Analisis Subyektif Dalam Manajemen Struktur Modal}

Dalam menentukan struktur modal perusahaan, manajemen juga menerapkan analisis subyektif (judgment) bersama dengan analisis kuantitatif yang telah dibahas didepan. Berbagai faktor yang dipertimbangkan dalam pembuatan keputusan tentang struktur modal adalah :

a) Kelangsungan hidup jangka panjang ( Long-run viability )

Manajer perusahaan, khusunya yang menyediakan produk dan jasa yang penting, memiliki tanggung jawab untuk menyediakan jasa yang berkesinambungan. Oleh karena itu, perusahaan harus menghindari tingkat penggunaan hutang yang dapat membahayakan kelangsungan hidup jangka panjang perusahaan.

b) Konservatisme manajemen

Manajer yang bersifat konservatif cenderung menggunakan tingkat hutang yang konservatif pula ( sedikit hutang ) dari pada berusaha memaksimumkan nilai perusahaan dengan menggunakan lebih banyak hutang.

c) Pengawasan

Pengawasan hutang yang besar dapat berakibat semakin ketat pengawasan dari pihak kreditor (misalnya, melalui kontrak perjanjian atau covenaut). Pengawasan ini dapat mengurangi fleksibilitas manajemen dalam membuat keputusan perusahaan.

d) Struktur aktiva

Perusahaan yang memiliki aktiva yang digunakan sebagai agunan hutang cenderung menggunakan hutang yang relatif lebih besar. Misalnya, perusahaan real estate cenderung menggunakan hutang yang lebih besar dari pada perusahaan yang bergerak pada bidang riset teknologi 
e) Risiko bisnis

Perusahaan yang memiliki risiko bisnis ( variabilitas keuntungannya ) tinggi cenderung kurang dapat menggunakan hutang yang besar ( karena kreditor akan meminta biaya hutang yang tinggi ). Tinggi rendahnya risiko bisnis ini dapat dilihat antara lain dari stabilitas harga dan unit penjualan, stabilitas biaya, tinggi rendahnya operating leverage, dll.

f) Tingkat pertumbuhan

Perusahaan dengan tingkat pertumbuhan yang tinggi membutuhkan modal yang besar. Karena biaya penjualan ( flotation cost ) untuk hutang pada umumnya lebih rendah dari fenation cost untuk jaminan, perusahaan dengan tingkat pertumbuhan yang tinggi cenderung menggunakan lebih banyak hutang dbanding dengan perusahaan dengan tingkat pertumbuhan rendah.

g) Pajak

Biaya bunga adalah biaya yang dapat mengurangi pembayaran pajak, sedangkan pembayaran dividen tidak mengurangi pembayaran pajak. Oleh karena itu, semakin tinggi tingkat pajak perusahaan, semakin besar keuntungan dari penggunaan pajak.

h) Cadangan kapasitas peminjaman.

Penggunaan hutang akan meningkatkan risiko, sehingga biaya mosal akan meningkat. Perusahaan harus mempertimbangkan suatu tingkat penggunaan hutang yang masih memberikan kemungkinan menambah hutang di masa mendatang dengan biaya yang relatif rendah.

\subsection{Tekanan Keuangan}

Financial distress atau kesulitan keuangan dapat diartikan sebagai ketidakmampuan perusahaan untuk membayar kewajiban keuangannya pada saat jatuh tempo yang menyebabkan kebangkrutan perusahaan. Financial distress juga didefinisikan sebagai tahap penurunan kondisi keuangan yang terjadi sebelum kebangkrutan atau likuidasi (Platt dan Platt, 2002). Perusahaan yang berada dalam kondisi financial distress akan memiliki arus kas negatif dan beberapa tahun perusahaan mengalami laba operasi negatif. Dari segi operasionalisasi perusahaan 
gejala financial distress nampak pada waktu perusahaan melakukan pemberhentian tenaga kerja atau menghilangkan pembayaran dividen. Sehingga jika perusahaan menghentikan operasinya dan perusahaan mengalami pelanggaran teknis dalam hutang dan diprediksi akan mengalami kebangkrutan pada periode yang akan datang. Kesulitan keuangan bisa digambarkan di antara dua titik ekstrim yaitu kesulitan likuiditas jangka pendek (yang paling ringan) sampai insolvency (yang paling parah). Kesulitan keuangan jangka pendek biasanya bersifat sementara, tetapi bisa berkembang menjadi parah. Pengelolaan kesulitan keuangan jangka pendek (tidak mampu membayar kewajiban pada saat jatuh tempo) yang tidak tepat akan menimbulkan permasalahan yang lebih besar yaitu menjadi tidak solvabel (jumlah utang lebih besar daripada jumlah aset) dan akhirnya mengalami kebangkrutan.

Manfaat informasi financial distress menurut Platt dan Platt (1991)) menyatakan kegunaan informasi jika suatu perusahaan mengalami financial distress adalah:

a) Dapat mempercepat tindakan manajemen untuk mencegah masalah sebelum terjadinya kebangkrutan

b) Pihak manajemen dapat mengambil tindakan merger atau takeover agar perusahaan lebih mampu untuk membayar hutang dan mengelola perusahaan dengan baik.

c) Memberikan tanda peringatan awal adanya kebangkrutan pada masa yang akan datang.

Pihak-pihak yang Memerlukan Informasi Prediksi Financial Distress dan Kepailitan Hanafi (2005) menyatakan bahwa hasil prediksi financial distress dan kepailitan perusahaan menjadi perhatian dari beberapa pihak. Pihak-pihak yang menggunakan model tersebut antara lain:

a) Kreditur

Hasil prediksi financial distress mempunyai relevansi terhadap institusi pemberi pinjaman, baik dalam memutuskan pemberian suatu pinjaman maupun menentukan kebijakan untuk mengawasi pinjaman yang telah diberikan. 
b) Investor

Hasil prediksi financial distress dapat membantu investor ketika akan menilai kemungkinan masalah suatu perusahaan dalam melakukan pembayaran kembali pokok dan bunga.

c) Pembuat peraturan (pemerintah)

Pemerintah mempunyai tanggung jawab mengawasi kesanggupan suatu model yang aplikatif untuk mengetahui kesanggupan perusahaan membayar hutang dan menilai stabilitas perusahaan.

d) Auditor

Model prediksi financial distress dapat menjadi alat yang berguna bagi auditor dalam membuat penilaian going concern suatu perusahaan.

e) Manajemen

Apabila perusahaan mengalami kebangkrutan maka perusahaan akan menanggung biaya langsung (fee akuntan dan pengacara) dan biaya tidak langsung (kerugian penjualan atau kerugian paksaan akibat ketetapan membayar hutang dan menstabilkan perusahaan individu, hal ini menyebabkan perlunya pengadilan), sehingga dengan adanya model prediksi financial distress diharapkan perusahaan dapat menghindari kebangkrutan dan menghindari biaya langsung dan tidak langsung dari kebangkrutan.

\subsection{Hipotesis}

\subsubsection{Modal Sosial dan Keputusan Pendanaan}

Modal sosial dapat menjelaskan bagaimana keputusan pendanaan yang diambil oleh perusahaan. Karena dengan modal sosial yang dimiliki, perusahaan akan memiliki relasi positif dengan pelaku ekonomi lainnya, dimana dengan adanya relasi ini akan memperkuat akses kepada sumber-sumber pendanaan dari luar. Semakin kuat relasi yang dibangun maka modal sosial akan makin banyak, dampak terhadap pendanaan adalah jumlah hutang yang dapat dihimpun akan lebih tinggi dan kemudahan akses terhadap sumber modal yang lebih variatif. Hal ini berbeda jika dibandingkan dengan relasi yang lemah atau formal karena penilaian yang berbasis kolateral nilai agunan. Dengan kuatnya modal sosial yang 
dimiliki maka perusahaan yang mampu membangun hubungan sosial yang baik dengan instutusi keuangan akan memiliki kesempatan untuk memperoleh fasilitas pembiayaan bunga rendah (Nguyen dan Ramachandran, 2006; Du et al, 2010).

\section{H1 : Modal sosial berpengaruh terhadap keputusan pendanaan.}

2.5.2. Keputusan Pendanaan dan Tekanan Keuangan

Keputusan pendanaan dapat pula diartikan sebagai keputusan yang menyangkut struktur keuangan perusahaan (financial structure). Struktur keuangan perusahaan merupakan komposisi dari keputusan pendanaan yang meliputi hutang jangka pendek, hutang jangka panjang dan modal sendiri. Setiap perusahaan akan mengharapkan adanya struktur modal optimal, yaitu struktur modal yang dapat memaksimalkan nilai perusahaan (value of the firm) dan meminimalkan biaya modal (cost of capital). Keputusan pendanaan yang diambil oleh perusahaan akan membuat struktur aset meningkat, bagi investor hal ini merupakan informasi positif tentang kinerja perusahaan di masa yang akan datang. Bagi internal perusahaan sendiri, penambahan jumlah modal atau hutang akan membuat perusahaan mendapatkan likuiditasnya kembali, selanjutnya berdampak pada berkurangnya tekanan keuangan yang dihadapi oleh perusahaan (Lang et al, 1992).

\section{H2 : Keputusan pendanaan berpengaruh terhadap tekanan keuangan}

\section{Metodologi}

\subsection{Populasi dan Sampel}

Populasi adalah gabungan dari seluruh elemen yang berbentuk peristiwa, hal atau orang yang menjadi yang memiliki karakteristik yang serupa yang menjadi pusat perhatian seorang peneliti karena itu dipandang sebagai sebuah semesta penelitian (Ferdinand, 2011:215). Populasi dalam penelitian ini adalah UMKM di Kota Semarang

Sampel yang digunakan adalah UMKM batik. Pemilihan sampel pada penelitian ini menggunakan metode purposive sampling. Pemilihan purposive sampling dilakukan karena peneliti memahami bahwa informasi yang dibutuhkan dapat diperoleh dari satu kelompok sasaran tertentu yang mampu memberikan 
informasi yang dibutuhkan untuk penelitian ini. Adapun kriteria dalam penentuan sampel ini adalah sebagai berikut :

a. UMK yang sudah menjadi binaan.

b. UMK sampel terpilih akan dilakukan wawancara terstruktur dengan menggunakan kuesioner.

3.2. Variabel Penelitian dan Pengukuran

Tabel 1. Definisi Operasional Variabel

\begin{tabular}{|c|c|c|}
\hline Variabel & Definisi Konsep, Operasional dan Indikator & Pengukuran \\
\hline \multirow{9}{*}{$\begin{array}{l}\text { Modal } \\
\text { Sosial }\end{array}$} & Perekat yang menyatukan masyarakat, hubungan-hubungan antar & Skala $1 \mathrm{sd} 7$ \\
\hline & manusia, orang melakukan apa yang dilakukannya terhadap & $1=\mathrm{STS}$ \\
\hline & sesamanya karena ada kewajiban sosial, timbal balik, solidaritas & $2=\mathrm{TS}$ \\
\hline & sosial dan komunitas. Ife dan Tesoriero (2008) & $3=\mathrm{ATS}$ \\
\hline & Kepercayaan : Adanya respon positif, Kemauan kerja sama dan & $4=\mathrm{N}$ \\
\hline & Adanya rasa toleransi & $5=\mathrm{AS}$ \\
\hline & Rasa memiliki : Berbagi informasi dan Memberikan solusi & $6=S$ \\
\hline & Budaya : Sejarah pemilik perusahaan, Sistem kepemilikan dan & $7=\mathrm{SS}$ \\
\hline & Hubungan antar pemilik dan pemasok. & \\
\hline \multirow{7}{*}{$\begin{array}{l}\text { Keputusan } \\
\text { Pendanaan }\end{array}$} & Keputusan pendanaan dapat pula diartikan sebagai keputusan yang & Skala $1 \mathrm{sd} 7$ \\
\hline & menyangkut struktur keuangan perusahaan (financial structure). & $1=\mathrm{STS}$ \\
\hline & Struktur keuangan perusahaan merupakan komposisi dari & $2=\mathrm{TS}$ \\
\hline & keputusan pendanaan yang meliputi hutang jangka pendek, hutang & $3=\mathrm{ATS}$ \\
\hline & Jumlah hutang: Hutang dagang, Hutang pada bank dan Hutang pada & $5=\mathrm{AS}$ \\
\hline & supplier & $6=S$ \\
\hline & Jumlah modal : Modal pemilik, Modal luar dan Penyisihan & $7=\mathrm{SS}$ \\
\hline \multirow{8}{*}{$\begin{array}{l}\text { Tekanan } \\
\text { Keuangan }\end{array}$} & Tekanan keuangan dapat diartikan sebagai ketidakmampuan & Skala 1 sd 7 \\
\hline & perusahaan untuk membayar kewajiban keuangannya pada saat & $1=\mathrm{STS}$ \\
\hline & jatuh tempo yang menyebabkan kebangkrutan perusahaan. Financial & $2=\mathrm{TS}$ \\
\hline & distress juga didefinisikan sebagai tahap penurunan kondisi & $3=\mathrm{ATS}$ \\
\hline & $\begin{array}{l}\text { keuangan yang terjadi sebelum kebangkrutan atau likuidasi (Platt } \\
\text { dan Platt. 2002). }\end{array}$ & $\begin{array}{l}4=N \\
5=A S\end{array}$ \\
\hline & Kemampuan membayar : Periode pembayaran hutang, Jumlah & $6=S$ \\
\hline & hutang yang dapat dibayar dan Termin yang dapat dipenuhi. & $7=\mathrm{SS}$ \\
\hline & $\begin{array}{l}\text { Penjualan : Penjualan kredit, Pembayaran penjualan dan Uang muka } \\
\text { penjualan. }\end{array}$ & \\
\hline
\end{tabular}




\section{Pembahasan}

Proses seleksi sampel dilakukan berdasarkan kriteria yang telah ditentukan diperoleh 36 responden yang mengisi kuesioner. Responden adalah UKM yang menjadi binaan Bank Indonesia, Bank Jateng, Bank BNI dan Bank BRI. Responden yaitu pelaku UKM Batik di Kota Semarang rata-rata menjawab setuju bahwa modal sosial dengan indikator kepercayaan, rasa memiliki dan budaya memang berpengaruh terhadap keputusan pendanaan. Pelaku usaha senantiasa membantu pihak lain apabila mereka sedang ada masalah dan saling berbagi informasi satu sama lain demi kemajuan usaha yang mereka tekuni. UKM Batik sangat memperhatikan sejarah berdirinya usaha, cerita tentang pemilik usaha dalam membangun dan memajukan usahanya, tata kelola yang baik, sikap yang responsif terhadap pihak lain, serta menjalin hubungan baik dengan pemasok.

Responden yaitu pelaku UKM Batik di Kota Semarang rata-rata menjawab setuju bahwa keputusan pendanaan yang dilihat dari jumlah hutang dan jumlah modal. Responden dalam usaha menambah jumlah modal secara langsung menggunakan dana pribadi. Selain itu dapat juga diperoleh dari pemodal diluar pemilik serta modal dapat ditambah dengan menyisihkan sebagian tertentu dari penghasilan usaha. Pemahaman responden mengenai tekanan keuangan dapat dijelaskan bahwa pelaku UKM Batik di Kota Semarang senderung mempertimbangkan pengaruh penjualan terhadap tekanan keuangan yang dialami pelaku usaha. Responden menyetujui jumlah uang muka yang besar sangat menguntungkan karena pembayaran uang muka merupakan keharusan bagi pelanggan dan barang yang dijual dengan sistem kredit cukup diminati oleh para pelanggan.

Pengujian validitas dan reliabilitas data menyimpulkan bahwa seluruh instrumen penelitian adalah valid dan reliabel. Sehingga hasil kuesioner dapat digunakan untuk menyimpulkan hipotesis penelitian melalui uji regresi secara parsial. 
Tabel 2. Analisis Regresi

\begin{tabular}{lll}
\hline R square 1 & & 0,0137 \\
R square 2 & 0,0084 \\
Koefisien modal sosial & 2,206 & Sig 0,038 \\
Koefisien keputusan pendanaan & 0,274 & Sig 0,004 \\
\hline
\end{tabular}

Sumber : data primer dioleh, 2017

Hipotesa pertama terbukti signifikan yaitu modal sosial berpengaruh terhadap keputusan pendanaan. Pelaku UKM Batik menyadari bahwa keeratan hubungan yang terjalin antara pelaku, pemasok dan pelanggan akan menjadi mata rantai yang membuat para pelaku UKM Batik akan memiliki budaya yang erat, rasa memiliki dan kepercayaan antar pelaku ekonomi yang baik sehingga akan berpengaruh terhadap keputusan pendanaan yang diambil oleh para pelaku UKM Batik. Apakah akan menggunakan hutang ataukah menggunakan modal sendiri. Jika dilihat dari deskripsi responden, para pelaku UKM Batik lebih memilih memenuhi kebutuhan pendanaannya dengan modal sendiri baru menggunakan hutang. Hutang dalam hal ini adalah hutang pada pemasok berupa bahan baku dan penangguhan pembayaran untuk pembelian material.

Hipotesa kedua yang menyatakan bahwa keputusan pendanaan berpengaruh terhadap tekanan tekanan keuangan juga terbukti signifikan. Hasil ini memberikan gambaran bahwa tekanan keuangan yang dialami oleh para pelaku UKM Batik dimungkinkan terjadi karena kesalahan dalam menentukan keputusan pendanaan. Jumlah hutang yang terlalu besar dan tidak diimbangi dengan percepatan konversi pembayaran barang akan membuat dalam jangka pendek para pelaku usaha mengalami kesulitan likuiditas. Dalam jangka panjang, kesulitan likuiditas ini akan membuat perusahaan mengalami potensi gagal bayar dan mengarah pada kebangkrutan.

\section{Kesimpulan}

Modal sosial dengan indikator kepercayaan, rasa memiliki dan budaya yang terbentuk di antara para pelaku UKM Batik berpengaruh terhadap keputusan keuangan. Komposisi jumlah hutang dan jumlah modal sebagai indikator keputusan pendanaan berpengaruh terhadap tekanan keuangan yang dialami para pelaku UKM Batik. 


\section{Daftar Pustaka}

Arthur G. Korteweg, 2007, The Costs Of Financial Distress Across Industries, Working Paper Series.

Almilia, Luciana Spica (2006), Prediksi Kondisi Financial Distress Perusahaan Go Public dengan Menggunakan Analisis Multinomial Logit, Jurnal Ekonomi dan Bisnis, Vol. VII, No.1.

Amiyatosh K. Purnanandam, 2007, Financial Distress And Corporate Risk Management: Theory And Evidence, Working Paper Series.

Brahmana (2007), Identifying Financial Distress Condition in Indonesia Manufacture Industry , Brimingham Bussines School, University of Brimingham United Kingdom.

Edith S. Hotchkiss, Kose John, Karin S. Thorburn, Robert M. Mooradian, 2008, Bankruptcy And The Resolution Of Financial Distress, Working Paper Series.

Fachrudin, Khaira Amalia (2008), Faktor-Faktor Yang Meningkatkan Peluang Survive Perusahaan Kesulitan Keuangan, Jurnal Manajemen Bisnis, Vol 1,No. 1, Januari:1-9.

Ferdinand, Augusty (2011), Metodologi Penelitian Manajemen, Semarang : Badan Penerbit Universitas Diponegoro

George J. Mailath, Andrew Postlewaite, 2006, Social Assets, Journal International Economic Review, Vol.47, PP. 1057-1091.

Gozhali, Imam (2011), Aplikasi Analisis Multivariate dengan Program IBM SPSS 19, Semarang : Badan Penerbit Universitas Diponegoro.

Harlan D. Platt, Marjorie B. Platt, 2008, Financial Distress Comparison Across Three Global Regions, Journal Of Risk And Financial Management, PP. 129-162, 2008

Harlan D. Platt, Marjorie B. Platt, 2006, Comparing Financial Distress And Bankruptcy, Review Of Applied Economics, Vol. 2, No.2, 2006.

Redouane Elkamhi, Christopher A. Parsons, Jan Ericsson, 2009, The Cost Of Financial Distress And The Timing Of Default, EFA 2009 Bergen Meetings Paper.

Takeo Hoshi, Anil Kashyap, David Scharfstein, 1990, The Role Of Banks In Reducing The Costs Of Financial Distress In Japan, Journal Of Financial Economics, Vol.27, PP.67-88.

Karen Hopper Wruck, 1990, Financial Distress Reorganisation And Organizational Efficiency, Journal Of Financial Economic, Vol.27, PP. 419444. 
Ohlson, J.A (1980), Financial Ratios and The Probabilistic Prediction of Bankruptcy, Journal of Accounting Research 18 (Spring ), Hlm. 109-130.

Outtecheva, Natalia (2007), Corporate Financial Distress: An Empirical Analysis of Distress Risk, Dissertation of the University of St.Gallen.

Platt \& Platt (2006), Understanding Differences Between Financial Distress and Bankruptcy, Review of Applied Economies. Vol. 2, No. 2, pp: 141-157. 